\title{
UNEMPLOYMENT AMONG YOUNG PEOPLE AS A FACTOR DETERMINING UNREGISTERED LABOR MARKET
}

\begin{abstract}
Changes which take place in the job market have a direct impact on the social and economic development of society. Instability, growing competition and the lack of new jobs force, especially young people to search for alternative ways of generating income and informal employment.

In this article informal employment, the rate of unemployment in Poland and the European Union as well as the structure of unemployment based on age groups in the years 2000-2014 have been analyzed. Based on statistic data an attempt was made to assess the impact of unemployment among young people on the unregistered labor market on the basis of the linear regression method. The results of a self conducted research were presented for the years 2007-2014 regarding the gray economy.

In this article an attempt was made to evaluate the relationship between the unemployment rate among young people in the age group between 15 to 34 and the share of informal labor in the GDP over all. The second objective of this article was to show the reasons why young people decide to search for unregistered labor.

The main reason for seeking employment on the black labor market is the lack of legal employment, it is assumed that higher unemployment is often closely associated with unregistered labor and the willingness to seek for such employment. Statistical data collected for the years 2000-2013 proves this hypothesis. Based on the linear regression method the number of unemployed in the two age groups under 25 and 25-34 has a significant impact on the share of the unregistered labor in the Gross Domestic Product and its statistical correlation is very high.

Keywords: labor market, undeclared work, unemployment.
\end{abstract}

\section{INTRODUCTION}

Currently countries and their governments experience many changes of political, social and economic nature. One of the major problems is unemployment, at this time we can observe its dramatic increase, it has a great impact on the economy, population and politics. We should focus on the problem of unemployment among the youngest participants of the work force.

The growing problem of unemployment among young people with higher education has a wide spectrum of negative effects and it is becoming very dangerous for society in which young people start their adult life from unemployment and lack of work, and in some cases illegal employment in the informal economy is the only way.

1 Dr Monika Pasternak-Malicka, Zakład Finansów, Bankowości i Rachunkowości, Wydział Zarządzania, Politechnika Rzeszowska, al. Powstańców Warszawy 10, 35-959 Rzeszów, tel.: (17) 86519 12, e-mail: malicka@ prz.edu.pl 
The phenomenon of informal employment is present in every economy in the world, in highly developed countries as well as in those less developed. The scale of informal employment is determined by many factors and differs between countries depending on political and social situation.

In this article, as a collective of young people (similar as in the study conducted by BAEL) the group of young people at the age range of 15 -34 years has been selected. This group is divided into two subgroups: those from 15 to approximately 25 , this is the age at which an average person graduates from college. The second subgroup 25-34 are those who enter the job market or continue their education.

This article will try to evaluate the impact of unemployment on the willingness to start work in the informal economy among young people at the age group under 25 years of age, as well as those between 25-34. The publication focuses mainly on informal employment in Poland and European Union, as well as unemployment among specific age groups. This article is based on the data obtained from the Central Statistical Office for the years 2000-2013. Based on the data collected an attempt was made to evaluate the effects of unemployment among young people and their willingness to participate in the informal job market based on the linear regression method. Public statistics were updated by data collected through a self- conducted study in the years 2007-2014 which focused on the gray economy as well as informal job market.

\section{DEFINITION AND SCALE OF THE ILLEGAL EMPLOYMENT}

The activity in the work market can be divided into three categories, legal employment, unregistered and illegal employment ${ }^{2}$. All are closely tidied together and are continuously changing and evolving, depending on the social and economic factors. The differences between illegal and unregistered labor are very slight, sometimes unregistered labor is defined as that which brakes formal procedures and illegal is associated with criminal activity, however because the differences are so minor they are treated as one.

We have to do with illegal employment when there is no written agreement between the employee and the employer, at that time the employee is unregistered and doesn't receive any social benefits. Self-employment can also be regarded as unregistered labor in the moment when a person avoids paying taxes ${ }^{3}$. According to law we have to do with illegal employment when there is no written agreement between the employee and the employer and the employee are not registered by the employer with the Social Security Services. Employing illegal emigrants or non-citizens without work permits is also considered as illegal employment ${ }^{4}$.

European Commission in 1998 described the problem of illegal employment and unregistered labor ${ }^{5}$. The commission stated that unregistered labor is work for which a person receives financial gratification but is unregistered with the proper governmental

\footnotetext{
${ }^{2}$ R. Hussmanns, Measuring the informal economy: from employment in the informal sector to informal employment, Working Paper No. 53, International Labor Office, December 2004, p. 15.

${ }^{3}$ S. Kostrubiec, Praca nierejestrowana w Polsce w 1998 roku, „Gospodarka Narodowa”, no. 5-6, 1999, p. 16; Praca nierejestrowana w Polsce w 2004 roku, GUS, Warszawa 2005, p. 8.

${ }^{4}$ Ustawa o promocji zatrudnienia i instytucjach rynku pracy z 20 kwietnia 2004, art. 2. poz. 13, Dz.U. poz. 674, $2013 \mathrm{r}$.

${ }^{5}$ Communication of the Commission on Undeclared Work, European Commission, COM (98)-219, Brussels 1998.
} 
institution $^{6}$. In the press release from 2013 the earlier definition was up holed and the only difference was that it incorporated the law regulations of the new European Union members into the new definition and was excluded from unregistered labor illegal activities such as (smuggling, drug trafficking, counterfeiting currencies, robbery). Experts in the field of the gray economy such as F. Schneider and B. Fogler also have excluded criminal activity from illegal labor ${ }^{7}$.

For the purpose of this publication it was assumed that informal employments is considered as the employment without a written agreement (contract) as well as overtime for which employee receives a salary "under the table," as well as unregistered selfemployment.

Fig 1. The Gray Economy in Poland 1994-2013 (i \%)

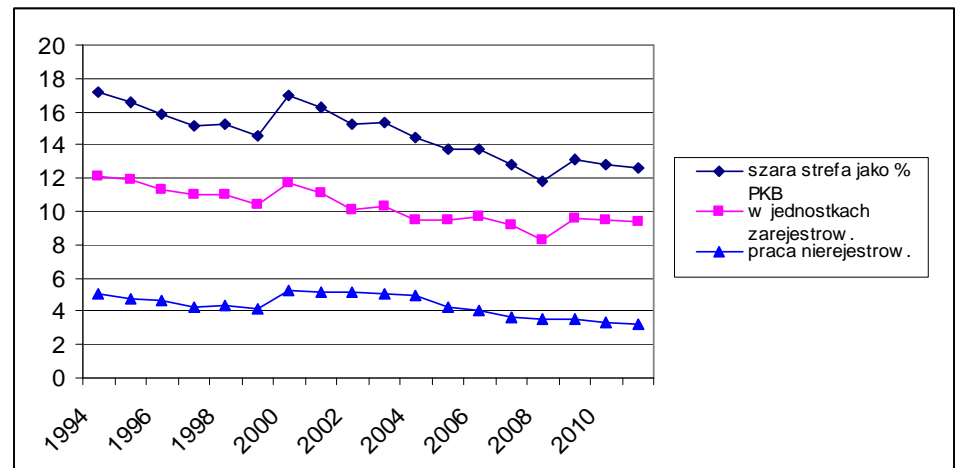

Source: Self-conducted study: Rachunki narodowe wg sektorów i podsektorów, GUS z lat 1995-2014.

Unregistered labor is a substantial part of the Polish labor market. Figure1 shows the share of the gray economy and unregistered labor in the Gross Domestic Product in the years 1994-2011 according to the Central Statistical Office, from 1994 to 2000 its share was somewhere between $15 \%-17 \%$, from the year 2001 its share of the national product stared to go down reaching the level of $11.8 \%$ in 2008. During the next few years it started to rise because of the drop in the national economic growth, and then it went up by approximately $1 \%$ to $2 \%$.

The best source of information regarding unregistered labor in Poland is the LFS (Labor Force Survey) regarding economic activity of population. The data collected by the Central Statistical Office shows that the number of people employed informally is systematically dropping from 1952.199 thousand, $1998-1.431$ thousand, $2004-1.317$ thousand, $2009-785$ thousand, $2010-732$ thousand, which is approximately $4.6 \%$ of the work force. In the years 1995 - 2010 the percentage of the unregistered employees in the

\footnotetext{
${ }^{6}$ Komunikat prasowy dotyczacy pracy nierejestrowanej oraz konsultacji ze zwiazkami zawodowymi $i$ przedstawicielami pracodawców, Komisja Europejska, 4 lipca 2013, Biuletyn informacyjny Komisji Europejskiej na temat zatrudnienia, spraw społecznych i włączenia społecznego, 2013.

${ }^{7}$ F. Schneider, Shadow Economies and Corruption All Over the World: New Estimates for 145 Countries; Jahannes Kepler University of Linz, Austria, 24 lipiec 2007 r., B. Torgler, F. Schneider, Shadow Economy, Tax Morale, Governance and Institutional Quality: A panel Analysis, IZA Discussion Paper Series 2007, pp. 9-10.
} 
total number of the people employed in Poland dropped from $14.89 \%$ of the workforce to $4.6 \%$, confronting that data with the population of 15 years of age and under from $7.6 \%$ to $2.3 \%{ }^{8}$.

The survey conducted by The Central Statistical Office shows that the largest age group that participates in the unregistered labor market is the 25 - 38 years of age group and it is approximately $28.8 \%$ of the total unregistered labor force, under 25 is approximately $19 \%$ of the labor force but for both of the age groups unregistered labor is the main source of income ${ }^{9}$.

Besides of the official publications and surveys conducted by CSO other studies are done to establish the size of the informal economy. Research conducted by F Schneider shows that informal economy in Poland is almost double the size compared to the values presented by CSO. According to the Austrian researcher the gray economy in Poland in 2010 reached the level of $26.4 \%$ of the national product, in $201224.4 \%$ in $201323.8 \%$ assuming that unregistered labor is approximately a third of gray economy it reached the level of $8.8 \%$ in $2010,8.1 \%$ in 2012 and $7.9 \%$ in $2013^{10}$.

\section{UNEMPLOYMENT AMONG YOUNG PEOPLE IN POLAND COMPARED TO OTHER EUROPEAN UNION COUNTRIES}

Extremely high unemployment rates among young people are a major problem in the European Union. Unemployment rate for the age group of 25 and under is more than double the size compared to other age groups ${ }^{11}$. According to International Labor Association in 2010 unemployment among young people at the age group 15-24 reached 75.8 million. In Poland the unemployment rate at this age group was $12.8 \%$ and in the EU $18.1 \%{ }^{12}$

In 20125517 million people under the age of 25 stayed without work in the EU and the unemployment rate for this age group reached $22.8 \%$ (compared to the age group 25-74 unemployment rate reached $9.1 \%)^{13}$. The southern region of the EU is in the worst position, in Greece more than half $(52.8 \%)$ of young people are without jobs, in Spain $(52.1 \%)$ of young people remain without steady employment, the situation is a little better in Slovakia( $38.8 \%$ ), Portugal and Italy (36\%), Bulgaria (28.5\%), Lithuania $(27.7 \%)$,

\footnotetext{
${ }^{8}$ Praca nierejestrowana w Polsce w 2010 r., Główny Urząd Statystyczny, Warszawa 2011, p.15.

${ }^{9}$ Obliczenia własne na podstawie: Praca nierejestrowana $w$ Polsce $w$ 2010, GUS, Warszawa 2011, p.68, 79 .

${ }^{10}$ A. Buehn, F. Schneider, Size and Development of Tax Evasion In the 38 OECD Countries: What do we (not) know?, CES info, Working Paper No. 4004, November 2012; F. Schneider, Size and Development of the Shadow Economy of 31 European and 5 other OECD Countries from 2003 to 2012, Some New Facts, CES info 2011, www. shadow-economy-size-percentage-gpd.xls; Schneider F., Size and Development of the Shadow Economy of 31 European and 5 other OECD Countries from 2003 to 2013, A Further Decline, http://www. econ.jku.at/members/ Schneider/files/ publications/2013/ ShadEcEurope31_Jan2013.pdf

${ }^{11} \mathrm{~J}$. Stecko, Value categories and the choice of youths in contemporarytimes, Humanities and Social Sciences, z.22(2/2015), s.155-161.

${ }^{12}$ Global Employment Trends 2012. Report International Labor Organization, 2012, s.92-93; www. ilo.org/global/publications/books/global-employment-trends.

${ }^{13}$ From the data collected by the Eurostat in the middle of the year 2013 without work was $23,3 \%$ of adults under 25 years of age, harmonized unemployment rate for the entire population of the EU calculated for the end of October was 11\% ; Eurostat 159/2013.
} 
Hungary (26\%), Sweden (24.6\%) and France (22.7\%). Germany had the lowest unemployment rate among young people (11\%) in 2007 and in 2012 it went down to $(9.7 \%)$. Austria also had an unemployment rate among young people bellow the EU average and it was $(8.3 \%)$.

The Eurostat data at the beginning of 2014 shows that $23.4 \%$ of the work force under 25 years of age stays unemployed. In the first quarter of 2014 unemployment among young people in the 28 EU countries increased by 39 million compared to May 2012 (January 20145556 million people). ${ }^{14}$ The lowest unemployment rate among young people was registered in Germany (7.6\%), Austria (10.5\%) and Holland (11.1\%), at the same time the highest rate was recorded in Greece (59\%), Spain (54.6\%), and Croatia $(49.8 \%)$.

In our country unemployment rates are not as dramatic as in the southern part of Europe. In Poland unemployment rate among young people reached $26 \%$ which places us on the $17^{\text {th }}$ position among the $28 \mathrm{EU}$ countries. The CSO counts the registered unemployment individuals that do not perform any tasks for which they receive payment and are able and willing to perform such tasks full time at the same time are not full time students and are registered with the unemployment office.

Table 1 presents the levels of unemployment in Poland in the years 2000-2013 the level of unemployment registered by LSF is not consistent because of the difficulties with defining the phenomena and the methodology used in the process of measuring the scale of the unemployment levels. The first value presented for unemployment rates is based on the data collected by Unemployment Office and the second is based on the data collected by LFS, in 2009 an increase in the unemployment rates can be observed that can be directly linked with the drop of the economic growth in Poland as well as globally.

Table 1. Unemployment levels registered by LSF in the years 200-2014 (\%)

\begin{tabular}{|l|l|l|l|l|l|l|l|l|l|l|l|l|l|l|l|}
\hline & 2000 & 2001 & 2002 & 2003 & 2004 & 2005 & 2006 & 2007 & 2008 & 2009 & 2010 & 2011 & 2012 & 2013 & 2014 \\
\hline $\begin{array}{l}\text { Regiterd une } \\
\text { mployment rale }\end{array}$ & 15,1 & 17,5 & 20,0 & 20,0 & 19,0 & 17,6 & 14,8 & 11,2 & 9,5 & 12,1 & 124 & 12,3 & 12,8 & 13,5 & 11,5 \\
\hline $\begin{array}{l}\text { Unemployment } \\
\text { rateacourdingto } \\
\text { LFS }\end{array}$ & 16,0 & 18,5 & 19,7 & 19,3 & 18,0 & 16,7 & 122 & 8,5 & 6,7 & 8,5 & 9,6 & 9,7 & 10,0 & 10,4 & 9,2 \\
\hline
\end{tabular}

Source: Self- conducted analysis based on CSO for the years 2000-2015.

The research conducted by Deutche Bank PBL in 2013 shows that at the age group 20-35 less than half $40.3 \%$ has a regular full time employment and $31.3 \%$ are unemployed. In Europe as well as in Poland unemployment is the main concern among the youngest job market participants. In the third quarter of 2013 the largest group among the unemployed are people 25-34 years of age and that is 602.3 thousand people the average for the third quarter is 640.6 thousand percentage wise it is $28.9 \%$ of the total unemployed people under 24 they make up for $19.1 \%$ of the total unemployed ${ }^{15}$.

People under 24 years of age make up for $19.1 \%$ of the total number of the unemployed. The number of unemployed in Poland in the years 200-2013 divided by the age group is presented in table 2. The largest percentage of unemployed workers in the

\footnotetext{
${ }^{14}$ Unemployment statistics, Eurostat styczeń 2014.

15 Dla mtodych wtasne mieszkanie to luksus, Sondaż Deutsche Bank PBC 2013, www. deutschebank.pl/ biuro-prasowe/ raporty-i-analizy
} 
age group of 25-34 in Poland was recorded in Lubelskie 33.2\%, Podkarpacie 30.8\%, Świętokrzyskie $30.0 \%$ and WIelkopolskim $29.7 \%{ }^{16}$.

Table 2. Number of unemployed in Poland in the years 2000-2014 divided by age in thousands

\begin{tabular}{|c|c|c|c|c|c|c|c|c|c|c|c|c|c|c|c|}
\hline $\begin{array}{l}\text { Numberof } \\
\text { unempbyed }\end{array}$ & 2000 & 2001 & 2002 & 2003 & 2004 & 2005 & 2006 & 2007 & 2008 & 2009 & 2010 & 2011 & 2012 & 2013 & 2014 \\
\hline Al trgether & 2702 & 3186 & 3375 & 3273 & 3081 & 2773 & 2309 & 1747 & 1474 & 1893 & 1755 & 1983 & 2137 & 2194 & 1825 \\
\hline b24 yeas & 823,5 & 942 & 941 & 885 & 781 & 266,1 & 476,7 & 3327 & 304,6 & 425,9 & 428,3 & 416,1 & 4112 & 408,6 & 302 \\
\hline 25-34years & 723 & 817 & 932 & 904 & 865 & 778,5 & 641,6 & 485,1 & 418,7 & 547,8 & 570,9 & 581,9 & 608,3 & 640,6 & 509 \\
\hline 35-44yeas & 651 & 762 & 730 & 694 & ๓2 & 567,0 & 4602 & 336,9 & 273,9 & 345,4 & 358,8 & 373,4 & 396,8 & 434,3 & 382 \\
\hline 45-54yeas & 481 & 571 & 664 & 969 & 655 & 6602 & 576,8 & 443,7 & 347,9 & 404,4 & 3972 & 385,3 & 389,4 & 399,8 & 340 \\
\hline $\begin{array}{l}55 \text { and } \\
\text { above }\end{array}$ & 113 & 94 & 108 & 131 & 139 & 1412 & 154,1 & 148,1 & १२८, & 1692 & 199,6 & 223,0 & 249,9 & 285,6 & 292 \\
\hline
\end{tabular}

Source: Self- conducted analysis based on CSO for the years 2000-2015.

The biggest problem with finding legal employment in Podkarpacie have young people under 35 years of age in the year 2000 it was $64 \%$ of all unemployed in 2013 that was $52 \%$ of all unemployed. During the time frame from 2000-2005 in Podkarpacie the age group 15-24 was characterized by the highest unemployment rate, where the number of registered unemployed reached the value of 59,8 thousand in 2000, 51 thousand. From the year 2005 the age group most significantly touched by the raise of unemployment was the group 25-34 in 2005 there was 51,9 thousand unemployed in this age group registered in the unemployment office and in 2013 it was 47 thousand people ${ }^{17}$.

\section{RELATIONSHIP BETWEEN UNEMPLOYMENT RATES AND THE NUMBER OF PEOPLE IN THE AGE GROUP OF 15-34 AND UNREGISTERED LABOR}

In the publication a linear regression method was used to observe if there is a dependence between unemployment rates and the number of unemployed young people. Figures 2-4 present the graphic spread correlation between the level of unregistered labor and unemployment rates among young people in the years 2000-2012, both charts show a distinctive dependence which means that growth of unemployment will have its impact on the level of unregistered labor.

Figure 2 presents the relationship between unregistered labor and unemployment rates in Poland in the years 2000-2012 using the linear regression to estimate the trend line, using the formula presented in the bottom corner of the drawing underneath the coefficient $\mathrm{R}^{2}$ that is the determination index ${ }^{18}$ its value was 0.7011 that means that both phenomena are very closely related.

16 Bezrobocie rejestrowane I-III kwartat 2013 r., Informacje i opracowania statystyczne GUS, Warszawa 2013, pp. 19, 38.

${ }^{17}$ Biuletyn statystyczny województwa podkarpackiego z lat 2003-2013.

18 Determination indicator has a value from 0 to 1 . If it is less than 0.5 it means that the model is misaligned with the observation. If it ranges from 0.5 to 0.6 - a poor fit, 0.6 to 0.8 - adjust satisfactory from 0.8 to 0.9 - good, and from 0.9 to 1 - very good. 
Figure 2. A scatter plot between the unemployment rate and the level of undeclared work

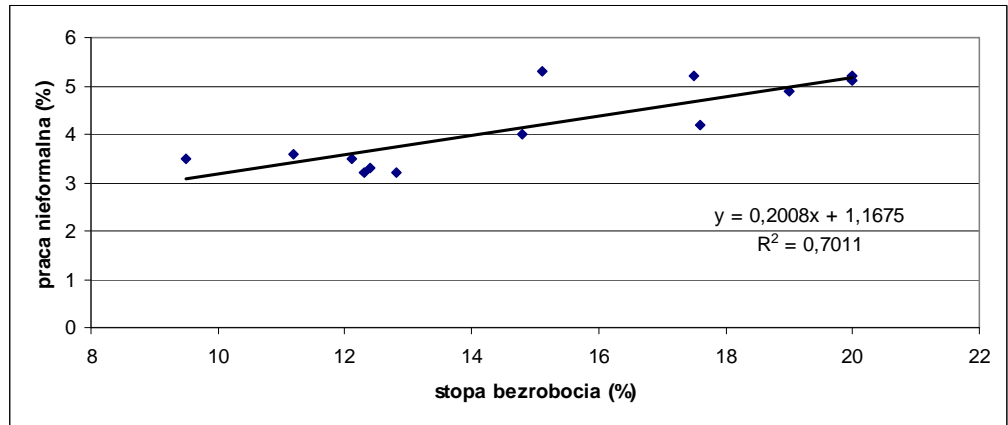

Source: Own calculations based on Table 1 and Figure1.

Graph 3 was created for the youngest age group of workers up to 25 years of age, it illustrates the relationship between unemployment and the share of the gross domestic product generated by unregistered labor by the already mentioned age group.

Figure 3.A scatter plot between the number of unemployed under 25 and the level of undeclared work

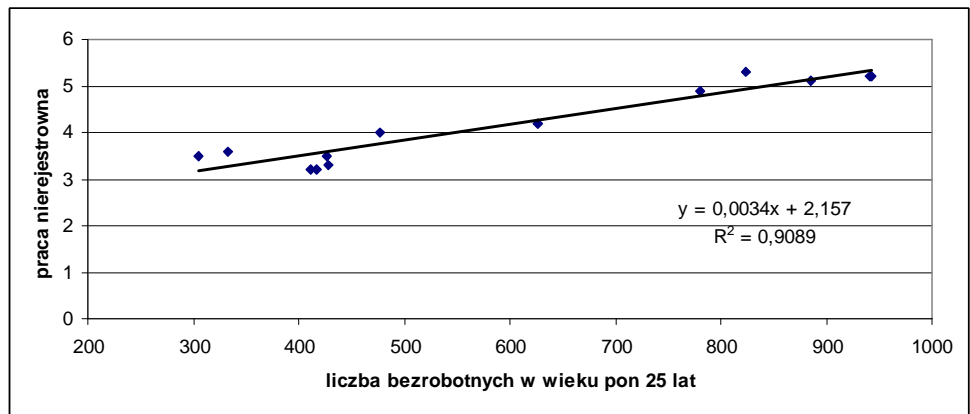

Source: Own calculations based on Table 2 and Figure1.

The value of the determining factor in this case reached 0.9089 that means $(91 \%)$, the dependence between the number of unemployed young people and the gray economy as well as unregistered labor stays closely related. The youngest age group of unemployed is most likely to seek unregistered employment, especially at times when the number of legal jobs offered is limited or non-existent. The youngest age group is often still at school and parents are economically responsible for their well-being, they most often seek part time employment and that is one of the characteristics of illegal employment. 
Figure 4. A scatter plot between the number of unemployed people aged 25-34 years and the level of undeclared work

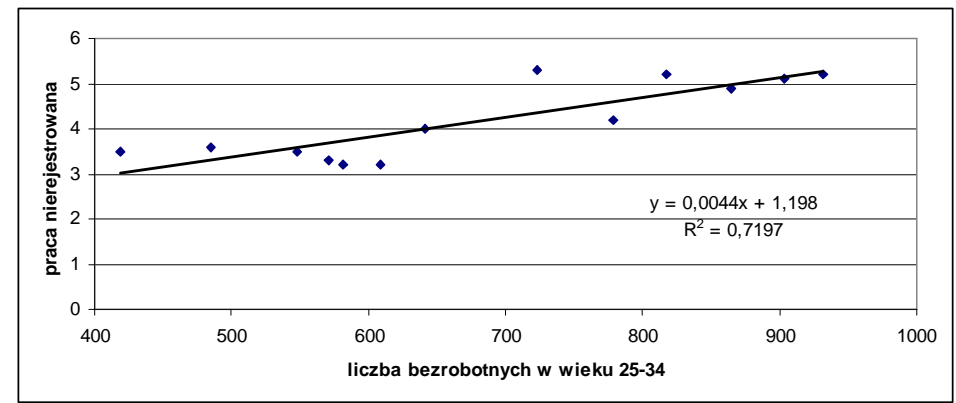

Source: Own calculations based on Table 2 and Figure1.

The situation is totally different when it comes to the age group 25-34 (graph 4) the correlation between the number of unemployed and the unregistered labor is not so strongly related, for this age group the correlation factor was only 0.7197 which means that only about $70 \%$ of the unemployed from this age group are willing to seek employment in the unregistered sector. At this age group potential employees are looking for more stability in their lives, they are starting to live on their own and that is why they are looking for financial independence so that they could afford mortgage payments, for example. To receive a mortgage it is required to have legal employment to receive a valid financial statement and get mortgage approved.

Older people are much more socially aware and other aspects of employment not just financial income play a significant part in terms of employment, for example gaining retirement benefits, health insurance, building financial creditability, at the same time faced with the lack of income and no means to support their families they are willing to seek employment in the unregistered labor market.

The relationship between these factors was shown on the charts 2-4 to check if the correlation is contingent. A test of correlation significance was made. Statistical tests are made to evaluate the relations observed during the test on the selected groups and if they are relevant for the whole population or if it is just coincidence, as a result of the statistical test probability is established and its feasibility is assessed, in all of the three presented correlations high dependency was observed during the test on the selected group and the relevance for the entire population was checked or was it just a coincidence, as a result of the statistical test probability $(p)$ is established and its feasibility is assessed ${ }^{19}$.

In all of the correlations presented high dependency was observed. The result of a statistical test so called test probability $(p)$ and its low value $(0.0004)$ certify that statistical tests are used to determine the statistical mortality. For the graph dispersion

\footnotetext{
${ }^{19}$ It is most often the following rules:

- when $\mathrm{p}>0.05$ are talking about no grounds to reject the null hypothesis, meaning that tested the difference, dependence, the effect is not statistically significant;

- when $\mathrm{p} \leq 0.05$ 're talking about a statistically significant relationship (mark this fact with *);

$\bullet \mathrm{p} \leq 0.01$ is highly significant dependence $(* *)$;

- $\mathrm{p} \leq 0.001$ is a highly significant statistical relationship $(* * *)$.
} 
between unregistered labor and the number of unemployed individuals in the age group under 25 years of age $\mathrm{p}^{\times \times \times x}$ factor reached the value of 0.00000 which means that statistical relationship is very high, in the third case $p^{x \times x \times}(0.0003)$ that means that statistical correlation is substantial.

\section{UNEMPLOYMENT AND SEEKING EMPLOYMENT IN THE UNREGISTERED JOB MARKET BY PERSONS JUST ENTERING THE JOB MARKET BASED ON A SELF-CONDUCTED STUDY}

Research conducted by Polish and international research centers show that receiving the status of the unemployed motivates to seek employment in the unregistered job market. Participants of the survey conducted by LSF in the years 1995-2010 acknowledged that a very important factor which motivates to seek unregistered employment was the lack of registered employment. In $199521.8 \%$ of the unemployed searched for unregistered employment compared to $53.1 \%$ in 2010 were willing to seek unregistered labor ${ }^{20}$. CASE study shows the influence of unemployment and the size of the unregistered labor market ${ }^{21}$. Among the most common reasons for seeking employment in the unregistered labor market is the lack of legal employment that is the most common answer among the unemployed in Germany, the United Kingdom and Hungary $^{22}$.

The report prepared by PIP (State Labor Inspectorate) work agency emphasizes that the majority of people employed in the unregistered market state that because they couldn't find legal employment they were forced to seek illegal employment ${ }^{23}$. Staying without employment, seeking and willingness to seek employment characterize unemployed individuals ${ }^{24}$.

The data collected through self-conducted in the years 2007-2014 shows that unemployment is one of the reasons that the unregistered labor phenomena accrues ${ }^{25}$. In literature concerning the subject of the gray economy as well as unregistered labor questioner surveys along with their many floes are the best way to research the subject and the structure of the unregistered labor market ${ }^{26}$.

Self-conducted study in the years from 2007- 2014 shows that among the leading causes of seeking employment in the unregistered labor market is the lack of legal

\footnotetext{
${ }^{20}$ Badania Ekonomicznej Aktywności Ludności, GUS

${ }^{21}$ Bednarski M., Kryńska E., Pater K., Walewski M., Przyczyny pracy nierejestrowanej w Polsce, Ministerstwo pracy i Polityki Społecznej, IPiSS, COBOS, CASE, MillwardBrown SMG/KRC, Warszawa 2008.

${ }^{22}$ Undeclared Work In the European Union. Report Directorate General Employment, Special Eurobarometer, October 2007, Table QB7T.

23 Państwowa Inspekcja Pracy, Sprawozdanie Gtównego Inspektora Pracy z dziatalności Państwowej Inspekcji Pracy w 2009 roku, Warszawa 2010, p.94.

${ }^{24}$ E. Kwiatkowski, Bezrobocie. Podstawy teoretyczne, PWN, Warszawa 2002, p. 16.

${ }^{25}$ Research was conducted on a target group of 686 households (in May 2007), 750 households (in May 2009), 1,084 households (in April and May 2010), 1,201 households (in May 2011), 1,230 farms home (in January 2012), 1,128 farms in January 2013 and 857 households (in January 2014.). In surveys conducted in May 2007 was attended by households from across the Polish, and interviews in the years 2009 to 2014 were carried out in Podkarpacie. The questionnaires were addressed to people over 20 years of age with different levels of income and standard of living.

${ }^{26}$ Przyczyny pracy nierejestrowanej, pod red. M. Bednarski ..., op.cit, p.56.
} 
employment and insufficient income generated through legal employment, these are the main reasons of seeking unregistered labor $35.5 \%$ of respondents have stated that lack of legal employment has driven them to seek employment on the unregistered market in 2013, (in $2007-23.6 \%, 2009-29.5 \%, 2010-31.6 \%, 2011-6.9 \%^{27}, 2012-33.3 \%$, $2013-35,5 \%)^{28}$

Table 3. Structure of the answers to the question about the reasons for taking up informal jobs by the age group

\begin{tabular}{|l|r|r|r|r|r|r|}
\hline \multirow{2}{*}{$\begin{array}{c}\text { Reasons for seeking } \\
\text { unregistered employment }\end{array}$} & \multicolumn{5}{|c|}{ Age } \\
\cline { 2 - 7 } & under 25 & $26-35$ & $36-50$ & $51-60$ & Above 60 & total \\
\hline insufficient income & $61(31 \%)$ & $72(41 \%)$ & $96(44 \%)$ & $56(38 \%)$ & $37(33 \%)$ & 322 \\
\hline higher pay without a contract & $66(36 \%)$ & $60(40 \%)$ & $55(30 \%)$ & $48(38 \%)$ & $17(16 \%)$ & 146 \\
\hline high income taxes & $44(26 \%)$ & $22(16 \%)$ & $35(19 \%)$ & $9(7 \%)$ & $16(19 \%)$ & 126 \\
\hline high insurance premium & $15(9 \%)$ & $20(13 \%)$ & $17(10 \%)$ & $25(22 \%)$ & $9(8 \%)$ & 86 \\
\hline family situation & $40(24 \%)$ & $38(26 \%)$ & $40(24 \%)$ & $36(31 \%)$ & $38(41 \%)$ & 192 \\
\hline $\begin{array}{l}\text { the lack of other job } \\
\text { opportunities }\end{array}$ & $93(63 \%)$ & $75(58 \%)$ & $90(59 \%)$ & $50(57 \%)$ & $54(72 \%)$ & 362 \\
\hline $\begin{array}{l}\text { low detectability and low } \\
\text { penalties }\end{array}$ & $7(5 \%)$ & $6(5 \%)$ & $8(6 \%)$ & $1(1 \%)$ & $2(3 \%)$ & 24 \\
\hline $\begin{array}{l}\text { the possibility of losing certain } \\
\text { benefits }\end{array}$ & $10(8 \%)$ & $3(3 \%)$ & $12(9 \%)$ & $6(7 \%)$ & $5(8 \%)$ & 36 \\
\hline other causes & $1(1 \%)$ & $0(0 \%)$ & $0(0 \%)$ & $0(0 \%)$ & $0(0 \%)$ & 1 \\
\hline
\end{tabular}

* Total exceeds $100 \%$ because respondents could indicate many variants of answers.

Source: Own calculations based on surveys conducted in 2014.

Difficulty in finding legal employment went up in 2014 and it reached $42.2 \%$ in that year. Table 3 shows what reasons were given by survey participants as those responsible for seeking employment in the informal job market, divided by age groups this problem was emphasized by the youngest participants of the job market up to 25 years of age and the oldest group over 60. Table 4 answers the questions regarding the structure and reasons for unemployment. It was based on the self-conducted study in 2014.

Table 5 presents the answers given to questions regarding the willingness to seek employment in the unregistered job market divided by age groups. Table 5 presents the structure of answers given to the questions regarding how you would react if you lost your job and could not find legal employment in $201479 \%$ of survey participants answered that they would seek employment on the unregistered labor market. In $201375.2 \%$ and in $201277 \%$ from which $52.6 \%$ would do so without any hesitation in $201343.7 \%$ in 2012 $48.3 \%$ this shows that unregistered labor is a phenomena which is socially accepted.

\footnotetext{
${ }^{27}$ Very low share of the determinants is clear from the facts that in 2011 the interviewees had to choose only one variant answers (in other years two variants).

${ }^{28}$ M. Pasternak-Malicka, Zatrudnienie nierejestrowane w kontekście problematyki bezrobocia, [w:] Praca Polaków, pod red. B. Kłos, A. Grycuka, Biuro Analiz Sejmowych Kancelarii Sejmu, Studia BAS, 4(36) 2013, Warszawa 2013, p.50.
} 
Table 4. Responses to the question of the impact of unemployment by age structure

\begin{tabular}{|c|r|r|r|r|r|r|}
\hline \multirow{2}{*}{ The effects of unemployment } & \multicolumn{5}{|c|}{ Age } \\
\cline { 2 - 7 } & under 25 & $26-35$ & $36-50$ & $51-60$ & above 60 & $\begin{array}{c}\text { Tota } \\
1\end{array}$ \\
\hline they agree to low wages & $78(40 \%)$ & $70(40 \%)$ & $88(40 \%)$ & $47(32 \%)$ & $41(36 \%)$ & 324 \\
\hline young people are not self-reliant & $51(26 \%)$ & $41(23)$ & $48(22 \%)$ & $42(29 \%)$ & $13(11 \%)$ & 195 \\
\hline unregistered labor & $22(11 \%)$ & $33(19 \%)$ & $32(15 \%)$ & $18(12 \%)$ & $32(28 \%)$ & 137 \\
\hline $\begin{array}{c}\text { they agree to mistreatment at } \\
\text { work }\end{array}$ & $17(9 \%)$ & $15(9 \%)$ & $26(12 \%)$ & $18(12 \%)$ & $13(11 \%)$ & 89 \\
\hline $\begin{array}{c}\text { they are depressed } \\
\text { the families of the unemployed of } \\
\text { ten fall apart }\end{array}$ & $17(9 \%)$ & $9(5 \%)$ & $2(1 \%)$ & $5(3 \%)$ & $4(4 \%)$ & 37 \\
\hline crime, alcoholism & $2(2 \%)$ & $1(1 \%)$ & $9(4 \%)$ & $7(5 \%)$ & $5(4 \%)$ & 26 \\
\hline $\begin{array}{c}\text { peopleon weffare oftenlose theirdesinetoseck } \\
\text { employment }\end{array}$ & $6(3 \%)$ & $0(0 \%)$ & $2(1 \%)$ & $4(3 \%)$ & $5(4 \%)$ & 17 \\
\hline athess & $0(0 \%)$ & $0(0 \%)$ & $0(0 \%)$ & $1(100 \%)$ & $0(0 \%)$ & 1 \\
\hline total & 197 & 176 & 219 & 145 & 114 & 851 \\
\hline
\end{tabular}

* Skipped variant lack of response.

Source: Own calculations based on surveys conducted in 2014.

Table 5. Responses to the question about the readiness to take informal work in case of job loss by age structure

\begin{tabular}{|l|r|r|r|r|r|r|}
\hline Q. In the event of job loss would / & \multicolumn{5}{|c|}{ Age } \\
$\begin{array}{l}\text { you be able / and willing / to seek } \\
\text { employment in the unregistered job } \\
\text { market? }\end{array}$ & under 25 & $26-35$ & $36-50$ & $51-60$ & above 60 & Total \\
\cline { 5 - 8 } & & & & & & \\
\hline Yes & $103(52 \%)$ & $91(52 \%)$ & $100(45 \%)$ & $91(61 \%)$ & $66(59 \%)$ & 451 \\
\hline Probably yes & $66(34 \%)$ & $52(30 \%)$ & $74(34 \%)$ & $22(15 \%)$ & $12(11 \%)$ & 226 \\
\hline Probably no & $7(4 \%)$ & $6(3 \%)$ & $11(5 \%)$ & $7(5 \%)$ & $2(2 \%)$ & 33 \\
\hline No & $8(4 \%)$ & $11(4 \%)$ & $8(4 \%)$ & $3(2 \%)$ & $12(11 \%)$ & 42 \\
\hline Don't know & $13(7 \%)$ & $16(9 \%)$ & $28(13 \%)$ & $26(18 \%)$ & $20(18)$ & 103 \\
\hline Together* & 197 & 176 & 221 & 149 & 112 & 855 \\
\hline
\end{tabular}

* Skipped variant of the other, and no response.

Source: Own calculations based on surveys conducted in 2014

Difficulty in finding legal employment is not the only reason for participating by individuals on the informal job market a great influence is also made by the tax payer morality ${ }^{29}$ and social acceptance of tax avoidance ${ }^{30}$, not without significance is the ability of government agencies to fight with the gray economy ${ }^{31}$.

${ }^{29}$ M. Pasternak-Malicka, Mentalność i moralność podatkowa a reakcje gospodarstw domowych na obowiazek podatkowy, Modern Management Review, Reserch Journal 20 (1/2013), Rzeszów 2013, pp.87-99.

30 M. Pasternak-Malicka, Uchylanie się od opodatkowania jako reakcja podatników na nieprzestrzeganie zasad podatkowych $w$ polskim systemie podatkowym, red. T. Famulska, A. Walasik, Finanse $w$ niestabilnym otoczeniu - dylematy $i$ wyzwania, Finanse publiczne, Zeszyty Naukowe Uniwersytetu Ekonomicznego w Katowicach, Katowice 2012, pp.353-365.

${ }^{31}$ M. Pasternak-Malicka, Rola kodeksu karno-skarbowego i kontroli skarbowej $w$ walce z szara strefa, Opodatkowanie Przedsiębiorstw, Zeszyty Naukowe Uniwersytetu Szczecińskiego nr 708, Szczecin 2012, pp.73-94. 


\section{CONCLUSIONS}

A significant problem in the EU is a very difficult situation in the job market. The diversity of the scale of the problem among the individual partners of the union reached an all-time high, on one side we have the courtiers that have a very low unemployment level (Germany, Austria), on the other hand we have countries that have a very high unemployment rate (Spain, Portugal, Greece, Cyprus) in these countries young people still are in a very difficult situation on the job market in countries such as Greece and Spain over half of young people are unemployed.

In Poland social statistics show that the unemployment rate among young people is on the rise especially at the age group 15-34 years of age. This age group is very sensitive and reacts quickly to the changes in the job market and more willing to seek employment in the informal market.

In Poland 5-8\% of the work force is employed without registration and the number is continuously dropping most often such employment is short term employment and the major age group represented in the unregistered labor market are employees 15-34 years of age, the research conducted by LSF shows that the main source of income in that age group comes from the unregistered labor market. The main reason for seeking employment in the black labor market is the lack of legal employment, it is assumed that higher unemployment is often closely associated with unregistered labor and the willingness to seek such employment. Statistical data collected for the years 2000-2013 proves this hypothesis. Based on the linear regression method the number of unemployed in the two age groups under 25 and 25-34 has a significant impact on the share of the unregistered labor in the Gross Domestic Product and its statistical correlation is very high.

The survey conducted shows that unemployed statute has an impact on the decision of individuals to seek unregistered labor however it is not the only reason for seeking employment in the gray economy sector, research conducted shows that it plays a significant role when deciding to search for employment on the unregistered labor market. It is very alarming that majority of survey participants state that they would be willing to seek unregistered employment when faced with the lack of legal employment opportunities, the most eager age group were young people in the age group under 25 years of age.

Unregistered labor is a very complex issue and there is no easy solutions for this problem. Illegal employment is a part of the gray economy and it is impossible to eliminate all together but through reducing the incentives which motivate to seek unregistered labor or by creating new legal employment opportunities can be successfully reduced.

\section{REFERENCES}

[1] Bezrobocie rejestrowane I-IV kwartat 2014 r., Informacje i opracowania statystyczne GUS, Warszawa 2015.

[2] Bezrobocie rejestrowane I-III kwartat 2013 r., Informacje i opracowania statystyczne GUS, Warszawa 2013.

[3] Buehn A., Schneider F., Size and Development of Tax Evasion In the 38 OECD Countries: What do we (not) know?, CES info, Working Paper No. 4004, November 2012. 
[4] Communication of the Commission on Undeclared Work, European Commission, COM (98)-219, Brussels 1998.

[5] Dla młodych własne mieszkanie to luksus, Sondaż Deutsche Bank PBC 2013, www. deutschebank.pl/ biuro-prasowe/ raporty-i-analizy Eurostat, publikacja $159 / 2013$.

[6] Global Employment Trends 2012. Report International Labor Organization, 2012, s.92-93; www. ilo.org/global/publications/books/global-employmenttrends.

[7] Informacja o sytuacji społeczno-gospodarczej kraju, GUS, Warszawa luty 2015.Komunikat prasowy dotyczacy pracy nierejestrowanej oraz konsultacji ze zwiazkami zawodowymi i przedstawicielami pracodawców, Komisja Europejska, 4 lipca 2013, Biuletyn informacyjny Komisji Europejskiej na temat zatrudnienia, spraw społecznych i włączenia społecznego, 2013.

[8] Kostrubiec S., Praca nierejestrowana w Polsce w 1998 roku, „Gospodarka Narodowa", nr 5-6, 1999

[9] Kwiatkowski E., Bezrobocie. Podstawy teoretyczne, PWN, Warszawa 2002.

[10]Państwowa Inspekcja Pracy, Sprawozdanie Gtównego Inspektora Pracy z działalności Państwowej Inspekcji Pracy w 2009 roku, Warszawa 2010.

[11]Pasternak-Malicka M., Mentalność i moralność podatkowa a reakcje gospodarstw domowych na obowiazek podatkowy, Modern Management Review, Reserch Journal 20 (1/2013), Rzeszów 2013, s.87-99.

[12]Pasternak-Malicka M., Rola kodeksu karno-skarbowego i kontroli skarbowej w walce z szara strefa, Opodatkowanie Przedsiębiorstw, Zeszyty Naukowe Uniwersytetu Szczecińskiego nr 708, Szczecin 2012, s.73-94.

[13]Pasternak-Malicka M., Uchylanie się od opodatkowania jako reakcja podatników na nieprzestrzeganie zasad podatkowych $w$ polskim systemie podatkowym, red. T. Famulska, A. Walasik, Finanse w niestabilnym otoczeniu-dylematy $i$ wyzwania, Finanse publiczne, Zeszyty Naukowe Uniwersytetu Ekonomicznego w Katowicach, Katowice 2012, s.353-365.

[14]Pasternak-Malicka M., Zatrudnienie nierejestrowane w kontekście problematyki bezrobocia, [w:] Praca Polaków, pod red. B. Kłos, A. Grycuka, Biuro Analiz Sejmowych [16] Kancelarii Sejmu, Studia BAS, 4(36) 2013, Warszawa 2013.

[15] Praca nierejestrowana w Polsce w 2004 roku, GUS, Warszawa 2005.

[16] Praca nierejestrowana w Polsce w 2010 r., GUS, Warszawa 2011.

[17]Schneider F., Bueth A., Montenegro C.E., Shadow Economies All over the Word. New Estimates for 162 Countries from 1999 to 2007, Working Paper 5356, lipiec 2010.

[18] Schneider F., Shadow Economies and Corruption All Over the World: New Estimates for 145 Countries; Jahannes Kepler University of Linz, Austria, 24 lipiec 2007.

[19] Schneider F., Size and Development of the Shadow Economy of 31 European and 5 other OECD Countries from 2003 to 2012, Some New Facts, CES info 2011, www. shadow-economy-size-percentage-gpd.xls.

[20] Schneider F., Size and Development of the Shadow Economy of 31 European and 5 other OECD Countries from 2003 to 2013, A Further Decline, http:// www. econ.jku.at/ members/ Schneider/ files/ publications/2013/ShadEcEurope31_Jan2013.pdf 
[21] Stecko J., Value categories and the choice of youths in contemporarytimes, Humanities and Social Sciences, z.22(2/2015), s.155-161.

[22] Torgler B., Schneider F., Shadow Economy, Tax Morale, Governance and Institutional Quality: A panel Analysis, IZA Discussion Paper Series 2007. Unemployment statistics, Eurostat styczeń 2014.

[23] Ustawa z dnia 20 IV 2004 r. o promocji zatrudnienia i instytucjach rynku pracy (Dz.U. z 2004 r. nr 99, poz. 1001 z późn. zm).

\section{BEZROBOCIE WŚRÓD MLODYCH LUDZI JAKO CZYNNIK DECYDUJACY O NIELEGALNYM RYNKU PRACY}

Zmiany jakie zachodzą na rynku pracy oraz ich społeczne i ekonomiczne skutki sprawiają, że współczesny rynek pracy staje się ważnym czynnikiem rozwoju społecznego i gospodarczego. Rosnący deficyt miejsc pracy, duża konkurencja i niestabilność zatrudnienia powodują, że człowiek, zwłaszcza młody, zmuszony jest do poszukiwania różnorodnych form pracy, w tym także pracy nieformalnej.

W publikacji została opisana istota nieformalnego zatrudnienia, poziom bezrobocia w Polsce i Unii Europejskiej, a także liczba bezrobotnych zarejestrowanych według struktury wiekowej w latach 2000-2013. Na podstawie danych statystycznych dokonano próby oceny wpływu poziomu bezrobocia wśród młodych osób na aktywność na nieformalnym rynku pracy w oparciu o metodę regresji liniowej. Zaprezentowano także fragmenty własnych badań ankietowych z lat 2007-2014 dotyczących szarej strefy, w tym pracy nieformalnej.

W opracowaniu starano się ocenić zależność pomiędzy stopą bezrobocia oraz liczbą bezrobotnych osób w wieku od 15 do 34 lat a udziałem pracy nieformalnej w PKB, z drugiej zaś strony, w oparciu o przeprowadzone badania ankietowe - wskazać przyczyny podejmowania pracy nieformalnej w opisywanej kategorii wiekowej.

Za jeden $\mathrm{z}$ głównych determinantów pracy nieformalnej uważa się brak miejsc pracy w sektorze oficjalnym. Przyjmuje się, że większemu bezrobociu towarzyszy na ogół wyższy udział pracy na rynku nieformalnym. Dane statystyczne z lat 2000-2013 zdają się potwierdzać występującą zależność. W oparciu o metodę regresji liniowej wykazano iż stopa bezrobocia i liczba bezrobotnych w dwóch kategoriach wiekowych (pon. 25 oraz 2534 lata) wpływa na udział pracy nieformalnej w PKB i zależność ta jest wysoce istotna statystycznie.

Także badania ankietowe wskazuja, iż status bezrobotnego może mieć wpływ na decyzję o podjęciu pracy nieformalnej, chociaż nie jest to jedyna przyczyna skłaniająca do zatrudnienia w szarej gospodarce

Słowa kluczowe: rynek pracy, praca nierejestrowana, bezrobocie.

DOI:10.7862/rz.2015.hss.37

Przesłano do redakcji: październik 2014

Przyjęto do druku: październik 2015 